\title{
IAMJ
}

INTERNATIONAL

AYURVEDIC

MEDICAL JOURNAL

\section{AYURVEDIC APPROACH ON CYSTOID MACULAR OEDEMA - A CASE REPORT}

\author{
Sabarinath M K ${ }^{1}$, S M Pasha²
}

PG Scholar, Dept. of PG studies in Shalakya Tantra, Government Ayurveda Medical College, Bengaluru, India HOD, Dept. of PG studies in Shalakya Tantra, Government Ayurveda Medical College, Bengaluru, India

\section{Corresponding Author: sabariatreya@gmail.com}

\section{https://doi.org/10.46607/iamj4809082021}

(Published Online: August 2021)

\section{Open Access}

(C) International Ayurvedic Medical Journal, India 2021

Article Received: 28/07//2021 - Peer Reviewed: 06/08/2021 - Accepted for Publication: 07/08/2021

\section{Check for updates}

\section{ABSTRACT}

Cystoid Macular Oedema or CME is a painless disorder that affects the central retina or macula. It refers to the accumulation of fluid in the outer plexiform and inner nuclear layer of the retina with the formation of a fluid-filled cyst. The primary symptom of macular oedema is blurry or wavy vision near or in the centre of your field of vision. Materials and Methods: A male patient of 48 yrs. presented in Shalakya OPD of GAMC Bengaluru with symptoms of diminished vision in his right eye for one year. The patient was diagnosed with cystoid macular oedema in the right eye for which he was given photocoagulation therapy but did not find much relief. So, he approached our OPD. After thorough examination patient was started with Ayurvedic Medicines. Result: The subject showed marked improvement both subjectively and objectively. Discussion: Oedema which is the terminus of the pathology in this condition has to be understood as Ekanga Shopha. Though Kapha is the predominant dosha involved in forming Shopha here, the lakshanas manifesting are that of Vataja Timira. So, in this case study, Kapha Vata Hara followed by Shopha Hara line of treatment is adopted.

Keywords: Cystoid macular oedema, Shopha, Vataja Timira, Nasya, Punarnavadi Kashaya. 


\section{INTRODUCTION}

The macula is the central part of the retina that plays an important role in acute and detailed vision and thus helps with tasks involving fine details such as reading and driving. Cystoid Macular Oedema refers to the collection of fluid in the outer plexiform (Henle's layer) and an inner nuclear layer of the retina, centred around the foveola like changes ${ }^{1}$. Presentation is with the blurring of vision especially for near tasks, and sometimes distortion. To correlate Cystoid Macular Oedema exactly to the disease mentioned in Ayurveda is difficult but it can be categorised under Drishtigata Roga with Vata Kapha involvement. The treatment is given based on Doshas involved.

\section{CASE REPORT}

Basic information of the patient, Age: 48, Sex: male, Religion: Hindu, Occupation: Engineer
Chief Complaints: Patient complaints of diminished vision in his right eye for one year.

History of present illness: The patient was said to be asymptomatic 1 year before. Then he gradually developed blueness of vision in the right eye. For this complaint, he approached an ophthalmologist and was diagnosed with cystoid macular oedema in the right eye for which he was given photocoagulation therapy, but did not find much relief. So he approached Shalakya OPD of GAMC Bengaluru.

History of past illness: The patient is a known case of Diabetes Mellitus for 5 years for which he was taking medicines and was under control.

Family history: Nothing significant.

Examination

Systemic examination: No abnormalities

\section{examination}

\begin{tabular}{|c|c|}
\hline Head posture & Normal posture \\
\hline Visual acuity & Distant vision PH Near Vision \\
\hline & RE $\quad 6 / 36 \quad 6 / 36 \mathrm{P} \quad \mathrm{N} 8$ \\
\hline & LE $6 / 12 \mathrm{P} \quad 6 / 12 \mathrm{P} \quad \mathrm{N} 6$ \\
\hline
\end{tabular}

\begin{tabular}{|l|l|l|}
\hline Distant direct ophthalmoscopic examination \\
\hline LE & Normal & \\
\hline RE & Cystoid macular oedema & Pale \\
\hline & Fundus & No demarcation in disc margin \\
\hline & Optic disc & Macular oedema \\
\hline & Macula & Loss of foveal contour \\
\hline & Fovea & \\
\hline
\end{tabular}

\section{Investigations}

\begin{tabular}{|l|l|}
\hline $\mathrm{Hb}$ & $13.4 \mathrm{gm} / \mathrm{dl}$ \\
\hline FBS & $120 \mathrm{mg} / \mathrm{dl}$ \\
\hline PPBS & $150 \mathrm{mg} / \mathrm{dl}$ \\
\hline HbA1C & $6.9 \%$ \\
\hline
\end{tabular}

OCT imaging was done. Given in figure number 1.

Diagnosis: Cystoid macular oedema.

Treatment given

\begin{tabular}{|l|l|l|l|}
\hline S no & Treatment & Drug and Dosage & Duration \\
\hline $\mathbf{1}$ & Deepana \& Pachana & Chitrakadi Vati 1 tid b/f & 3 days \\
\hline $\mathbf{2}$ & Sadyo Virechana & Gandharvahastadi taila $2(30 \mathrm{ml})$ & 1 day \\
\hline $\mathbf{3}$ & Nasya & Anutaila 8 drops in the morning & 7 days \\
\hline
\end{tabular}




\begin{tabular}{|c|c|c|c|}
\hline 4 & Seka & Triphala \& Punarnavadi Kashaya & 7 days \\
\hline 5 & Shiro Talam & Asanamanjistadi Taila \& Kachooradi Choorna & 7 days \\
\hline 6 & Takradhara & Musta + Amlaki Kashaya Sadhita Takra & 7 days \\
\hline 7 & Shamanoushadi & $\begin{array}{l}\text { 1. Punarnavadi Kashaya }{ }^{3}+\text { Varunadi Kashaya } \\
{ }^{2}(20 \mathrm{ml} \mathrm{BD} \mathrm{b/f)} \\
\text { 2. Chandraprabha Vati }{ }^{4} 2 \mathrm{BD} \mathrm{A} / \mathrm{f} \\
\text { 3. Shiva Gutika } 1 \mathrm{BD} \mathrm{A} / \mathrm{f}\end{array}$ & $\begin{array}{l}\text { During the treatment time, the fol- } \\
\text { lowing drugs were administered at } \\
\text { appropriate times. }\end{array}$ \\
\hline 8 & Rasayana & Dashamoola Haritaki Lehya ${ }^{5} 1$ tsp at night after food & 1 month \\
\hline
\end{tabular}

Result: Much improvement was observed both subjectively and objectively as shown below the table.

\begin{tabular}{|l|l|l|}
\hline Visual acuity & R E & L E \\
\hline After 15 days & $6 / 24$ & $6 / 12$ \\
\hline After 1 month & $6 / 18 \mathrm{P}$ & $6 / 12$ \\
\hline After 2 months & $6 / 12 \mathrm{P}$ & $6 / 9 \mathrm{P}$ \\
\hline HbA1C & $6.1 \%$ & \\
\hline Distant Direct Ophthalmoscopy & Oedema in the macular region reduced. No cystic space around the foveal region. \\
\hline
\end{tabular}

\section{DISCUSSION}

We can't find a direct correlation of Cystoid Macular Oedema in Ayurveda. Oedema which is the terminus of the pathology in this condition has to be understood as Ekanga Shopha. Though Kapha is the predominant dosha involving in forming Shopha here, the lakshanas manifesting are that of Vataja Timira.

Probable mode of action:

Chitrakadi Vati: - was given for Ama Pachana and Vatanulomana action. Virechana Dristi is pitta sthana. Hence Virechana is the first line of treatment for most Drishtigata Rogas. Here it clears the avarana of Kapha and Pitta to vata dosha. Nasya: Nasya is given to bring Pitta Vata Shaman in Drishti and does Indriya Dridakarana. Seka:-with Chakshushya Dravyas like Punarnava and Triphala reduces oedema by mechanical pressure and increases the bioavailability of drugs. Shirotalam: - with Kachooradi Choorna (Tridosha shamaka, Raktapitta hara, Sukshma Srotogami) and Asana Manjistha Thaila (which does Pitta Samana in Drishti). The active ingredients of the medicinal paste which is covered over the scalp will cross the cell membrane and enter into the circulation. Takradhara: Takradhara on Shiras is claimed to be a unique remedy for disorders of Shiras, Karna and Netra. Hence it is employed here for added benefit. Shamanoushadis: Punarnava Kashaya is Tikta Rasa
Pradhana, Shothahara, Rasa Rakta Prasadana. Varunadi Kashaya is Kapha Medo Hara, Antarvidradhi Hara. Chandraprabha Vati is Balya, Rasayana, Tridoshahara, Vatanulomana, Medohara, Sopha Hara. Shiva Gutika is Balya Rasayana, having Lekhana action Dashamoola Haritaki Lehya is Rasayana, which is having Sarvanga Sopha Hara action.

\section{CONCLUSION}

Cystoid macular oedema is considered a major visionthreatening disease. But ayurvedic medicines have a good role in many ophthalmic diseases. A well planned combined therapy can result in good outcomes with patient satisfaction. Ayurvedic Panchakarma therapies along with Netra Kriya Kalpas and Shamanoushadis in a planned way is found to be effective in treating Cystoid Macular Oedema with a better visual outcome.

\section{REFERENCES}

1. A K Khurana. Comprehensive Ophthalmology. \# $6^{\text {th }}$ Edition; The Health Science Publisher New Delhi, Chapter 12, page no 294.

2. Acharya Vagbhata. Asthanga Hrudaya with the commentaries (Sarvanga Sundara) of Arundatta and (Ayurveda Rasayana) of Hemadri. Edited by 
Bhisagacharya Harisastri Paradkar Vaidya. \# Varanasi: Chaukhambha Orientalia. Sutra sthana, chapter 15, sloga 21-22, page 236.

3. Shri Vallabhacarya. Vaidya Chintamani was edited with an English translation and explanatory notes by $\mathrm{K}$

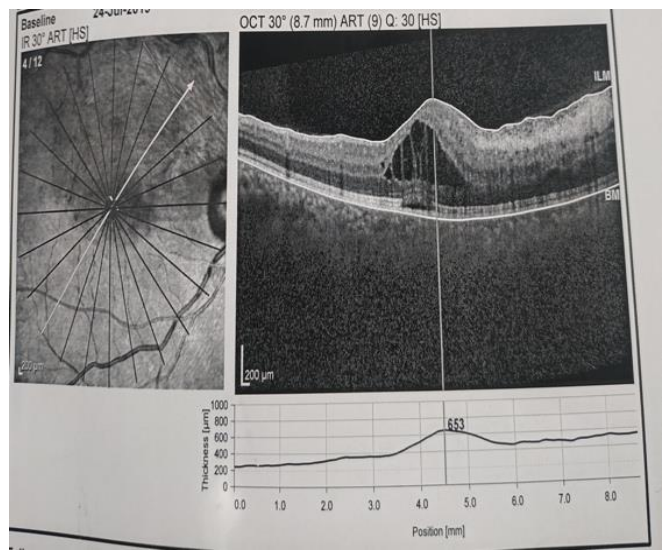

Figure 1: OCT BEFORE TREATMENT
Ramachandra Reddy. Varanasi: Chaukhambha Orientalia, 2013; chapter 10, sloga 34, page 397.

4. Shri Govinda Dasji. Bhaisajyaratnavali edited by Bhishagratna shri Brahmashankar Mishra. \# Varanasi: Chaukhambha Orientalia, 2014 edition; chapter 9, sloga 222-233, page 615-616.

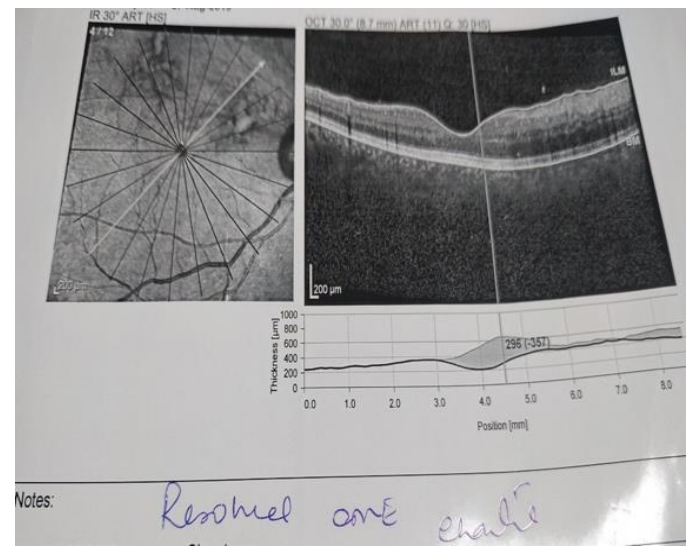

Figure 2: OCT AFTER TREATMENT

\section{Source of Support: Nil \\ Conflict of Interest: None Declared}

How to cite this URL: Sabarinath M K \& S M Pasha: Ayurvedic Approach On Cystoid Macular Oedema - A Case Report. International Ayurvedic Medical Journal $\quad$ online $\quad 2021 \quad$ \{cited August 2021\} Available from: http://www.iamj.in/posts/images/upload/1904_1907.pdf 